\title{
FEDERAL RESTRICTIONS ON STATE CRIMINAL PROCEDURE
}

\author{
Bennetr Boskey* and John H. Pickernng $\dagger$
}

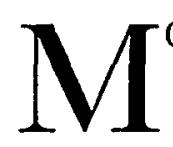

ORE than a century ago, in Cohens v. Virginia, ${ }^{\mathrm{x}}$ Chief Justice Marshall set at rest the last genuine doubts as to the jurisdiction of the Supreme Court to review state judgments in criminal cases which involve a federal question. Throughout the years that branch of its business has continued to bring to the Supreme Court substantive issues of vast public importance, for the criminal case has served as one of our traditional modes of testing the validity of state legislation. Particularly during the past fifteen years, however, the Court has found itself increasingly concerned with the procedural side of state criminal law enforcement; more and more the Court has been required to sit in judgment on the fairness of the procedure in state criminal cases, and to decide whether or not a state has obtained a conviction in violation of the procedural safeguards established by the Fourteenth Amendment."

Under our federal system the sovereignty of the states over matters primarily of local concern, such as the enforcement of their own criminal laws, makes the Supreme Court's function in reviewing state criminal procedures necessarily a narrow one. ${ }^{3}$ Yet it is not so narrow that the basic assurances of a fair trial are sacrificed. The introduction of a coerced confession into evidence, the systematic exclusion of members of the defendant's race from juries, the denial of counsel where counsel is essential to protect the rights of the accused, the knowing use of perjured testimony by the prosecution-all these are vices which the Fourteenth Amendment proscribes. Convictions so obtained are subject to reversal. Although the reversal in no way settles the guilt or innocence of the accused, it

* Adviser on Enemy Property Problems, U.S. Department of State.

$\dagger$ Member of the New York Bar.

I 6 Wheat. (U.S.) 264 (I82r).

"Section $x$ of the Fourteenth Amendment provides:

"All persons born or naturalized in the United States, and subject to the jurisdiction thereof, are citizens of the United States and of the State wherein they reside. No State shall make or enforce any law which shall abridge the privileges or immunities of citizens of the United States; nor shall any State deprive any person of life, liberty, or property, without due process of law; nor deny to any person within its jurisdiction the equal protection of the laws."

${ }_{3}$ See Buchalter v. New York, 3I9 U.S. 427 (I943); Palko v. Connecticut, 302 U.S. $3^{\text {Ig }}$ (1937); Twining v. New Jersey, 2Ir U.S. 78 (I908); Hurtado v. California, IIo U.S. $5^{\text {I6 }}$ (I884). 
means that on a retrial the coerced confession must be excluded, the jury fairly chosen, the right to counsel accorded, or the tainted testimony withheld.

These principles, now firmly fixed as the law of the land, were slow in unfolding. The obligation of the states to abide by the procedural safeguards of the Fourteenth Amendment was given judicial recognition as early as I880, in Strauder v. West Virginia ${ }^{4}$ - the first Supreme Court reversal of a conviction on the ground that systematic exclusion of Negroes from the jury had violated the federal rights of a Negro defendant. But during the next half-century-while the Fourteenth Amendment was becoming a crowded asylum for business enterprises fleeing from the regulatory power of the states-the Amendment's procedural guaranties suffered gross neglect.

Thus by the end of the I920's only a few additional restrictions on state criminal procedure had emerged: Moore v. Dempsey5 ruled that a state court trial dominated by the threat of mob violence was a nullity; Tumey v. Ohio outlawed a fee system which made the trial judge's compensation directly dependent on his convicting and fining the accused; and Manley v. Georgia ${ }^{7}$ held unconstitutional a statutory presumption that every bank insolvency was to be deemed fraudulent unless the officers proved that they had carefully administered the bank's affairs. Neither the denial of the right to counsel nor the introduction of a coerced confession nor the knowing use of perjured testimony had yet been assessed in the light of the Due Process Clause, and it was not until the Scottsboro cases that the full scope of federal limitations on state criminal procedure began to appear.

\section{THE SCOTTSBORO CASES}

The Scottsboro cases stand out among the causes célèbres of our generation. Some Southern communities-convinced from the outset that the

4 100 U.S. 303 (1880).

${ }_{2} 26$ I U.S. 86 (I923). The Supreme Court held that a federal district court on an application for habeas corpus should have inquired into the verity of the allegations. The subsequent history of the case is discussed in Waterman and Overton, The Aftermath of Moore v. Dempsey, I8 St. Louis L. Rev. II7 (1933). All twelve Negroes originally sentenced to death for participation in the Elaine riot were ultimately released, six by direction of the Supreme Court of Arkansas, Ware v. State, $x 59$ Ark. 540, 252 'S.W. 934 (1923) and Martin v. State, 162 Ark. 282, 257 S.W. 752 (1924), and the other six by action of the Governor of Arkansas.

${ }^{6} 273$ U.S. 5 ro (1927).

7279 U.S. I (1929). See also Morrison v. California, 29I U.S. 82 (I934). Compare the decisions striking down state presumptions in peonage cases. Pollock v. Williams, 322 U.S. 4 (I944); Taylor v. Georgia, 3I5 U.S. 25 (1942); Bailey v. Alabama, 2Ig U.S. 2Ig (IgII). On the general subject of constitutional restrictions on statutory presumptions, see Note, 56 Harv. L. Rev. 1324 (r943). 
Negro defendants were guilty-were stirred to bitter resentment by the efforts of "outsiders" to secure the most vigorous possible defense for the accused. Zealous supporters of the defense, for their part, were equally convinced that the two white complainants, Victoria Price and Ruby Bates, had not been raped by the defendants (indeed, Ruby Bates soon recanted ${ }^{8}$ ), and that the case was being pressed solely to vindicate malevolent local bigotry. Whatever the ultimate truth of the matter, the trials aroused emotions, not readily quieted, which are hardly suggested by the bare legal chronology.

The cases began on March 25, I93I, when nine youthful and illiterate Negroes were arrested at Paint Rock, Alabama, charged with criminally attacking two white girls on a freight train earlier that day. The nine were Clarence Norris, Charlie Weems, Haywood Patterson, Andy Wright, Roy Wright, Eugene Williams, Willie Roberson, Ozie Powell and Olen Montgomery. On March 3 I they were indicted for rape by a Jackson County grand jury. They were given no fair opportunity to employ counsel of their own choice, and counsel were not assigned until a few moments before the trials began on'April 6. In an atmosphere of considerable tension the defendants were tried in three separate groups; the juries convicted all but Roy Wright (disagreeing as to him), and fixed the punishments at death. The Alabama Supreme Court affirmed seven of the judgments (and set aside Williams' conviction on the ground that he was a juvenile ${ }^{9}$ ) but the Supreme Court of the United States reversed..$^{10}$ The Court found violation of the Due Process Clause because the defendants-ignorant, helpless, and on trial for their lives-had not been accorded the right to the assistance of counsel in any substantial sense. That conclusion was rested on two separate grounds. First:

In the light of the facts outlined in the forepart of this opinion-the ignorance and illiteracy of the defendants, their youth, the circumstances of public hostility, the imprisonment and the close surveillance of the defendants by the military forces, the fact that their friends and families were all in other states and communication with them necessarily difficult, and above all that they stood in deadly peril of their lives-we think that the failure of the trial court to give them reasonable time and opportunity to secure counsel was a clear denial of due process.

Then in the alternative:

But passing that, and assuming their inability, even if opportunity had been given, to employ counsel, as the trial court evidently did assume, we are of opinion that,

${ }^{8}$ Ruby Bates, appearing as a surprise witness for the defense at the second trial of Haywood Patterson, testified that her previous testimony had been false and had been inspired by the other prosecutrix, Victoria Price. New York Times, April 7, I933.

9224 Ala. 524, 531, 540, 14I So. 215, 195, 201 (I932).

Io Powell v. Alabama, 287 U.S. 45 (I932). 
under the circumstances just stated, the necessity of counsel was so vital and imperative that the failure of the trial court to make an effective appointment of counsel was likewise a denial of due process within the meaning of the Fourteenth Amendment. Whether this would be so in other criminal prosecutions, or under other circumstances, we need not determine. All that it is necessary now to decide, as we do decide, is that in a capital case, where the defendant is unable to employ counsel, and is incapable adequately of making his own defense because of ignorance, feeble-mindedness, illiteracy, or the like, it is the duty of the court, whether requested or not, to assign counsel for him as a necessary requisite of due process of law; and that duty is not discharged by an assignment at such a time or under such circumstances as to preclude the giving of effective aid in the preparation and trial of the case. To hold otherwise would be to ignore the fundamental postulate, already adverted to, "that there are certain immutable principles of justice which inhere in the very idea of free government which no member of the Union may disregard." In a case such as this, whatever may be the rule in other cases, the right to have counsel appointed, when necessary, is a logical corollary from the constitutional right to be heard by counsel.ri

On remand the cases were transferred to Morgan County. Patterson, first to be retried, was found guilty, but the trial judge set the verdict aside as against the weight of the evidence. Patterson's third trial before another judge ended in conviction and sentence of death. The court overruled his contention that, contrary to the Equal Protection Clause, Negroes had been systematically excluded from juries in Jackson County, where the indictment was found, and in Morgan County, the place of trial; and the Alabama Supreme Court in affirming held that the bill of exceptions containing the evidence on the Negro-exclusion issue had not been filed in time. ${ }^{22}$

Retrial of Norris immediately followed Patterson's third conviction. Similar evidence of Negro exclusion was held insufficient, and Norris, too, was convicted and sentenced to death. Although the Alabama Supreme Court thought no case of exclusion had been made out, ${ }^{x_{3}}$ the Supreme Court of the United States once more reversed, ruling that the record showed systematic exclusion of Negroes from both the grand and petit juries in violation of the Equal Protection Clause. ${ }^{14}$ In finding an unconstitutional discrimination in the administration of the Alabama jury statute, the Court examined the evidence "in order that the appropriate enforcement of the federal right may be assured." In Jackson County, the record showed, no Negro had been called to serve on any jury for a generation or longer; although the names of Negroes were, under the jury commission practice, included on the preliminary list, none ever reached the jury roll; the jury commissioners "never discussed" whether individual Negroes

\footnotetext{
Ir Ibid., at $7 \mathbf{1}-2$.

I2 Patterson v. State, 229 Ala. 270 , 156 So. 567 (r934).

13 Norris v. State, 229 Ala. 226, r56 So. 556 (1934).

${ }^{4}$ Norris v. Alabama, 294 U.S. 587 (I935).
} 
were for some reason disqualified; and it affirmatively appeared that qualified Negroes lived in the county. For Morgan County similar evidence had been adduced; accordingly, the jury commissioners' statements that no one was excluded on account of race or color were rejected by the Court as "mere generalities" insufficient to rebut the showing that exclusion had been lnog-continued and that many Negroes were qualified to serve.

At the same time, the Court vacated the judgment in Patterson's case to afford the state court an opportunity, in view of the Norris decision, to examine its power to entertain Patterson's tardy bill of exceptions on the exclusion issue..$^{\text {I5 }}$ On May I6, I935, the Alabama Supreme Court ordered the indictments against both Norris and Patterson quashed..$^{16}$

New indictments were then returned against all nine defendants. At Patterson's fourth trial, the judge denied a petition for removal of the case to the federal district court under Section $3^{I}$ of the Judicial Code; ${ }^{\text {I7 }}$ the jury returned a verdict of guilty, directing a sentence of seventy-five years; the Alabama Supreme Court affurmed in June, $1937{ }^{\times 8}$ and in October certiorari was denied. ${ }^{x 9}$ Meanwhile, in July, Norris, Andy Wright and Weems were also convicted; the juries fixed Norris' punishment at death (commuted by the Governor that same month to life imprisonment ${ }^{20}$ ), Wright's at ninety-nine years, and Weems' at seventy-five years; and the Alabama Supreme Court upheld the convictions. ${ }^{2 \mathrm{~T}}$

On July 24, when four of the defendants (Patterson, Norris, Andy Wright and Weems) stood convicted, the State nolle prossed the rape charges against the five who remained..$^{22}$ Roy Wright, Williams, Roberson

25 Patterson v. Alabama, 294 U.S. 600 (1935).

${ }^{26}$ New York Times, May 17 , x935:

${ }^{17}{ }^{6} 6$ Stat. Iog6 (IgIr), 28 U.S.C.A. $\$ 74$ (I927). This section permits removal of criminal cases from state courts when the defendant "is denied or can not enforce in the judicial tribunals of the State.... any right secured to him by any law providing for the equal civil rights of citizens of the United States. ...."

${ }^{18}$ Patterson v. State, 234 Ala. 342, 175 So. 37I (I937).

19 Patterson v. Alabama, 302 U.S. 733 (1937). $\quad{ }^{20}$ New York Times, July 6, 1938.

2I Norris v. State, 236 Ala. 281 , I82 So. 69 ( $\left.x_{93} 8\right)$; Wright v. State, 236 Ala. 263 , $x 82$ So. 5 (1938); Weems v. State, 236 Ala. 26r, I82 So. 3 (r938).

$\approx$ A formal statement issued by the prosecution announced that (I) every lawyer connected with the prosecution was convinced that Roberson and Montgomery were not guilty; (2) Roberson had been suffering from a severe venereal disease, which would have made it painful and unlikely for him to commit rape, and from the beginning he had told a very plausible story showing his innocence; (3) Montgomery had been practically blind at the time of the crime, and had also given a very plausible alibi, so that the continued insistence by the prosecutrix upon Montgomery's guilt "we feel . . . is a case of mistaken identity"; and (4) Roy Wright and Williams had been only twelve and thirteen years old at the time of the crime, and in view of their incarceration for six and a half years counsel for the state thought the ends of justice would be met by releasing them "on condition that they leave the state, never to return." New York Times, July 25, 1937. 
and Montgomery were permitted to go free, some six and one-half years after the beginning of their ordeal. Powell, however, was sentenced to twenty years after pleading guilty to assault with intent to murder-during one of the numerous trips between the jail and the courthouse he had slashed a deputy sheriff in an attempt to escape. ${ }^{23}$

The Scottsboro cases gave an unmistakable hint of the Fourteenth Amendment's full scope as the protector of helpless defendants caught in a grossly unfair or discriminatory state court criminal proceeding. The Supreme Court's rulings, besides awakening members of the bar, helped to instill in state judges a new sense of responsibility for insuring fair procedures. The decisions thus became a great stimulus in the development of the law.

\section{THE RIGHT TO COUNSEL}

The basic importance of the right to the assistance of counsel was succinctly stated by Mr. Justice Sutherland in the first Scottsboro case:

[The] right to be heard would be, in many cases, of little avail if it did not comprehend the right to be heard by counsel. Even the intelligent and educated layman has small and sometimes no skill in the science of law. If charged with crime, he is incapable, generally, of determining for himself whether the indictment is good or bad. He is unfamiliar with the rules of evidence. Left without the aid of counsel he may be put on trial without a proper charge, and convicted upon incompetent evidence, or evidence irrelevant to the issue or otherwise inadmissible. He lacks both the skill and the knowledge adequately to prepare his defence, even though he have a perfect one. He requires the guiding hand of counsel at every step in the proceedings against him. ${ }^{24}$

So far as federal criminal prosecutions are concerned, those persuasive considerations are buttressed by the Sixth Amendment's express guaranty that "the accused shall enjoy the right.... to have the Assistance of Counsel for his defence." In a series of decisions-all subsequent to the Scottsboro cases, and beginning with Johnson v. Zerbst $2^{25}$-the Supreme Court has construed the Sixth Amendment, as applied to federal prosecutions, "to require appointment of counsel in all cases where a defendant is unable to procure the services of an attorney, and where the right has not been intentionally and competently waived." ${ }^{26}$ Johnson v. Zerbst also

${ }_{23}$ By January, I944, Weems, Andy Wright, and Norris had been released on parole; in September, I944, Norris was returned to jail as a delinquent, the parole authorities announcing he had refused to work. New York Times, January 8, I944; Montgomery Advertiser, January 7, I944; Washington Post, September 28, I944.

24 Powell v. Alabama, 287 U.S. $45,68-69$ (I932).

${ }^{25} 304$ U.S. $45^{8}$ (1938); Walker v. Johnston, $3^{\text {I2 }}$ U.S. 275 (I94I); Holiday v. Johnston, 3 I3 U.S. 342 (I94I); White v. Johnston, 313 U.S. 538 (I94I); Centers v. Sanford, 3I5 U.S. 784 (1942); Adams v. United States ex rel. McCann, 3I7 U.S. 269 (I942); United States ex rel. McCann v. Adams, 320 U.S. 220 (1943); cf. United States ex rel. Robinson v. Johnston, 3 I6 U.S. 649 (I942); see Glasser v. United States, 3 I5 U.S. 60 (r942).

${ }^{26}$ Betts v. Brady, 316 U.S. $455,464-65$ (I942). 
made it clear that the question of deprivation of right to counsel could be raised in a habeas corpus proceeding collaterally attacking a federal judgment of conviction; a defendant unconstitutionally deprived of counsel, and who (very likely for that reason) has failed to take a timely appeal, obviously should not be left wholly without remedy in the courts. ${ }^{27}$

The Supreme Court's broad construction of the Sixth Amendment did not, however, settle the scope of the obligation of the states. The Court had not touched on the question whether the Sixth Amendment's guaranty of the right to counsel was-as were the First Amendment's guaranties of freedom of speech, press, and religion-specifically incorporated into the Due Process Clause of the Fourteenth Amendment. Indeed, it was not even clear from the first Scottsboro decision whether the rule there established would be applied to noncapital cases, or to cases where the utter helplessness of the defendant was a less conspicuous element in the record.

No new principle emerged in Avery v. Alabama, ${ }^{28}$ since the Court after scrutiny of the record was satisfied that Avery had been afforded adequate opportunity to prepare his defense with the aid of counsel. But at its I940 term Smith v. O'Grady' reached the Court. In I932 Albert Smith, arraigned in a Nebraska state court, had received a twenty-year sentence upon pleading guilty to a charge of burglary with explosives-a crime punishable by twenty years to life imprisonment under Nebraska law. In I 940 he applied to a state court for habeas corpus, alleging in great detail that state officers had tricked him into pleading guilty on the promise of a three-year maximum sentence; that he had been denied any real notice of the charge preferred against him; that immediately after the pronouncement of sentence he had sought to withdraw his plea of guilty and had requested the appointment of counsel to advise him, but that the court had denied his requests; and that the original sentence was not appealed because of the trial court's failure to appoint, and his inability to obtain, counsel. Smith's claim that his confinement was consequently in deprivation of his rights under the Due Process Clause was rejected by the Lancaster County district court without a hearing, on the ground that no cause of action was stated-a decision affirmed by the Nebraska Supreme Court in an unreported order. The Supreme Court of the United States held, however, that Smith had set forth a cause of action under the Due

${ }^{27}$ See Boskey and Braucher, Jurisdiction and Collateral Attack, $40 \mathrm{Col}$. L. Rev. 1006, 1028 (I940). Habeas corpus may also be used to attack a federal conviction if the defendant was coerced into pleading guilty or was insane at the time of entering such a plea. Waley v. Johnston, 316 U.S. ror, ro4-5 (I942); Frame v. Hudspeth, $3 \circ 9$ U.S. 632 (1940).

${ }^{28} 308$ U.S. 444 (1940).

${ }^{29} 312$ U.S. 329 (194r). 
Process Clause and that, since habeas corpus did not appear to be an improper remedy under Nebraska law, he was entitled to an opportunity to offer supporting proof. ${ }^{3 \circ}$

At the following term, Betts v. Brady ${ }^{3 \mathrm{x}}$ left to the states a freedom of action not permitted to the federal government. Betts had been indicted for robbery in a state court in Carroll County, Maryland. A farm hand, out of work and on relief, he was unable to employ counsel; at his arraignment he so informed the judge and requested that counsel be appointed. This the judge refused, stating it was not the practice in Carroll County to designate counsel for indigent defendants except in murder and rape cases. Betts then elected to be tried without a jury; he cross-examined the prosecution's witnesses and called his own to establish an alibi. The judge found him guilty and imposed a sentence of eight years. Betts later applied to Judge Bond, Chief Judge of the Maryland Court of Appeals, for a writ of habeas corpus, alleging he had been deprived of his right to counsel in violation of the Due Process Clause. Judge Bond denied the application on the merits, taking the view that the trial had not run counter to the Constitution.

In this he won the concurrence of six justices of the United States Supreme Court. The Supreme Court extensively examined the history of state requirements for furnishing counsel to indigent defendants. Mr. Justice Black's dissenting opinion pointed out that thirty-five states have some clear legal requirement or established practice that counsel be provided on request to indigent defendants not only in capital cases but in serious noncapital cases (e.g., where the crime charged is a felony, a "penitentiary offense," or an offense punishable by several years' imprisonment). The majority opinion, on the other hand, gave great weight to the fact that in many of those states the requirement appeared to rest on statute rather than state constitutional provision, and that in a large number of instances states had treated the appointment of counsel as a question of legislative policy. The Court concluded that the limitation which the Sixth Amendment imposes on the federal courts is not fully operative against the states-that the Sixth Amendment's rule is not so essential to a fair trial as to be part of the due process of law guaranteed by the Fourteenth.

${ }^{30}$ The effect of the reversal, of course, was not to release Smith from prison but to bring his application on for hearing in the Lancaster County district court. That court conducted an exhaustive inquiry into the facts and, upon evidence sharply conflicting, came to the conclusion that Smith's story was an elaborate fiction. From devastatingly adverse findings of fact Smith took no appeal. His subsequent applications to other courts for writs of habeas corpus met with no success. E.g., Ex parte Smith, 319 U.S. 727 (I943); Ex parte Smith, 317 U.S. 592 (I942).

${ }^{32} 316$ U.S. 455 (1942). 
The Court found additional support in the special circumstances of the case. In Maryland it is the usual practice for the defendant to waive trial by jury, as Betts had done, and the trials thus tend to be more informal, with the judge in a better position to control their course; the issue at the trial had been relatively simple, turning wholly on the veracity of Betts' alibi witnesses; and there were no affirmative indications that Betts had been helpless or at a serious disadvantage. These considerations failed to persuade the dissenting justices that fundamental ideas of fairness and right would countenance a man on trial for a serious crime being deprived of counsel merely because of his poverty.

Although in Betts v. Brady the Court declined to carry over the Sixth Amendment's guaranty inexorably into the Fourteenth, the opinion admonished state courts to discharge their responsibility for protecting the rights of indigent defendants, and noted that in particular cases the want of counsel might result in a conviction lacking in fundamental fairness.

Determination of the scope of the obligation of the states was thus remitted to a case-by-case adjudication, with Ex parte Haw ${ }^{32}$ next in the series. In I936 Hawk had been convicted of murder in a Nebraska state court and sentenced to life imprisonment. Applying to the Supreme Court of the United States for habeas corpus, Hawk alleged that, while a federal prisoner at Leavenworth, he had been taken to Omaha to stand trial in the state court for first-degree murder, that after arriving in Omaha at $4:$ I 5 P.M. he was arraigned at 9 the next morning, that the case immediately proceeded to trial and his motion for a twenty-four-hour continuance was denied, that he had no opportunity to confer with two attorneys from the public defender's office who appeared in his behalf, and that he did not want those two attorneys as his counsel. Hawk's effort to obtain relief from the federal courts was held premature, since he had not exhausted his remedies in the state courts. The Supreme Court stated, however, that he was entitled to a hearing in some tribunal on his claim that he had been forced into trial for a capital offense with such expedition as to deprive him of the effective assistance of counsel. Hawk then made similar allegations in a habeas corpus application to the state court; the Nebraska Supreme Court held he was not entitled to a hearing but the Supreme Court of the United States reversed, ruling that Hawk should have an opportunity to prove his charge that no effective assistance of counsel had been furnished in the critical time between the plea of not guilty and the calling of the jury. ${ }^{33}$

Hawk's allegations were considerably more specific than those in ${ }^{32} 321$ U.S. II4 (I944). ${ }^{33}$ Hawk v. Olson, 66 Sup. Ct. II6 (I945). 
Williams v. Kaiser. ${ }^{34}$ Williams had been sentenced to twenty years upon pleading guilty to robbery by means of a deadly weapon (a capital crime in Missouri). Four years later he applied for habeas corpus to the Missouri Supreme Court, alleging the following as a violation of his rights under the Due Process Clause of the Fourteenth Amendment:

Prior to his conviction and sentence, as aforesaid, the petitioner requested the aid of counsel. At the time of his conviction, as aforesaid, the petitioner was without the aid of counsel, the Court did not make an appointment of counsel, nor did the petitioner waive his constitutional right to the aid of counsel, and he was incapable adequately of making his own defense, in consequence of which he was compelled to plead guilty.

The Missouri Supreme Court denied the petition, without opinion and without a hearing, because it "fails to state a cause of action." The Supreme Court of the United States thought that this was intended to constitute a denial on the merits of the federal rights asserted. ${ }^{35}$ In reversing the judgment the Court held that the allegations, if proved, were sufficient to establish a violation of the Due Process Clause. The Court once more emphasized the difficulties confronting the average layman who goes to trial unassisted by counsel, and pointed out that assistance is particularly important in reaching a decision on whether to enter a plea of guilty"a decision which is irrevocable and forecloses any possibility of establishing innocence." The Court also observed that Missouri made important distinctions between various degrees of robbery and larceny, which could hardly be comprehended without expert advice.

A companion case, Tomkins v. Missouri, ${ }^{36}$ brought a similar reversal. Tomkins had pleaded guilty to first-degree murder and received a life sentence. Ten years later he applied for habeas corpus to the Missouri Supreme Court, alleging that at his trial,

he was not represented by counsel, the court did not make an effective appointment of counsel, the petitioner did not waive his constitutional right to the aid of counsel, and he was ignorant of his right to demand counsel in his behalf, and he was incapable adequately of making his own defense.

The Supreme Court of the United States recognized that the petition had not been drawn with the desirable precision and clarity, but thought that the substance of the claim was clear and that Tomkins was entitled to a

${ }^{34} 323$ U.S. 47 I (1945).

35 The Court noted (I) that the state made no claim that habeas corpus was not the proper remedy, under Missouri law, for this type of case, and (2) that under Missouri law a defendant who requests counsel is presumed, in the absence of evidence to the contrary, to have been without counsel and without funds to employ counsel.

${ }^{36}{ }^{323}$ U.S. 485 (1945). 
hearing. Still another case, Mackey v. Kaiser, ${ }^{37}$ was shortly afterward remanded to the Missouri Supreme Court for further consideration in the light of the Williams and Tomkins decisions.

In House v. $M a y o^{38}$ the defendant's complaint was not that the Florida state court, which had sentenced him to twenty years for burglary, had failed to appoint counsel. House's petition for habeas corpus claimed that he had his own attorney, but that while the attorney was temporarily out of town the information was handed up without previous notice, that his request for time to communicate and consult with his attorney was denied, that he was forced to plead guilty within a few minutes after receiving a copy of the information, and that at the time he was in his twenties, uneducated, and a stranger in the town. Such a trial would have been no less a sham than the one alleged in Smith v. O'Grady, and the Supreme Court held that House's assertions, if proved, would establish an unconstitutional denial of a reasonable opportunity to consult counsel.

White v. Ragen, ${ }^{39}$ like the first Scottsboro case, presented a question of the ineffectiveness of appointed counsel. White, upon pleading guilty, had been given a one- to ten-year sentence in Illinois for obtaining money and goods by means of the confidence game. His petition for habeas corpus alleged that the attorney appointed to represent him did not confer with him until they came to court for trial, and then refused to do anything unless White had some money, that White wished one witness called in his behalf but the attorney replied that "he did not have time, as he had a case in another court, and for me to plead guilty, as the judge would not give me a continuance." The petition went on to say that White asked the judge for a continuance so that he could call a witness and confer with his attorney, that the judge told White "to keep still, as his lawyer would do all the talking for him," and that the attorney thereupon pleaded White guilty. The Supreme Court held these allegations of fact sufficient to make out a prima facie case of a violation of White's rights under the Due

${ }^{37} 323$ U.S. 683 (I945). Mackey had pleaded guilty and received a life sentence for rape. His petition for habeas corpus alleged that the plea had been entered for him by the sheriff, without his consent, that he was in a dazed condition at the trial and not in possession of all his faculties, that he was wholly ignorant of the nature and import of the proceedings and wholly ignorant of his legal rights, that he was denied the right to consult with an attorney and friends, and that he was denied the right to the aid of counsel and did not waive that right.

${ }^{38} 324$ U.S. 42 (I945). In applying to the federal district court for habeas corpus House had claimed that he had exhausted his state court remedies. The Supreme Court held that the federal district court should have inquired into that question, since House deserved a hearing on the merits in some court.

${ }^{39} 324$ U.S. 760 (I945). 
Process Clause, stating that White was entitled to invoke the corrective process of some court-federal if not state-to obtain a hearing..$^{\circ 0}$

In Rice v. Olson, ${ }^{4 \pi}$ decided the same day, the Court overruled a state court's finding that the right to counsel had been waived. Rice, an Indian, had received a sentence of one to seven years upon pleading guilty in a Nebraska state court to a charge of burglary. His petition for habeas corpus, filed in a state court, alleged that the trial judge had failed to advise him of his constitutional rights to counsel and to call witnesses, that he had not waived these rights, and that the alleged crime had been committed on an Indian reservation exclusively within federal jurisdiction. Rice did not obtain a hearing on his allegations, and the Nebraska Supreme Court in affirming held that a plea of guilty constitutes an absolute waiver of the right to counsel when the defendant makes no request that counsel be assigned to him. The Supreme Court of the United States, however, ruled that the question of waiver was a question of fact, not absolutely foreclosed by a plea of guilty, since "it is enough that a defendant charged with an offense of this character is incapable adequately of making his defense, that he is unable to get counsel and that he does not intelligently and understandingly waive counsel." The Court added that Rice's need for legal counsel at his trial was emphasized by the complex questions of law involved in determining whether the place where the alleged offense occurred actually was within exclusive federal jurisdiction. In remanding the case for further proceedings, the Court in no way limited the power of Nebraska to consider the plea of guilty as strong evidence of a waiver of the right to counsel; it merely outlawed a rule of law which treated the plea, regardless of the circumstances under which it had been entered, as a conclusive, incontrovertible waiver.

Canizio v. New York,,$^{4^{2}}$ a coram nobis proceeding instituted in 1945 , turned on whether counsel had arrived on the scene too late to render effective assistance. On June I, I93I, Canizio had pleaded guilty to firstdegree robbery, and on June ig he had received a sentence of fifteen to thirty years. He was then nineteen years old and unfamiliar with legal

$4^{\circ}$ White had filed an original application for habeas corpus in the Supreme Court of Illinois, which denied it without hearing or opinion. The Supreme Court dismissed its writ of certiorari after oral argument, because upon examination of Illinois decisions it could not say that the judgment did not rest on an adequate non-federal ground-namely, that the Illinois Supreme Court would entertain no original application for habeas corpus which might involve the trial of an issue of fact. White was thus left to apply for relief to the lower state courts, or if necessary to the federal courts.

${ }^{4} 324$ U.S. 786 (I945).

${ }^{4 \mathrm{~h}} 66$ Sup. Ct. $45^{2}$ (r946). 
proceedings; he claimed the judge had failed to advise him of his right to counsel. It appeared, however, that on June I7, after the plea of guilty had been entered, a lawyer had filed a notice of appearance on Canizio's behalf, and that during long hearings on the day of sentence the lawyer had actively represented him and endeavored to secure a low sentence. Under New York law counsel could have moved to withdraw the plea of guilty when he took over Canizio's defense, although he had not chosen to make such a motion. The New York court accordingly concluded that Canizio had obtained counsel in ample time to take advantage of every defense which would have been available to him originally. The Supreme Court, with Justices Murphy and Rutledge dissenting, took the same view, holding that Canizio actually had the benefit of counsel at his trial.

There, for the time being, this line of decisions comes to a halt. But the Court will soon be compelled to resume its inquiries - to begin the laborious task of quieting title, parcel by parcel, to the vast area which lies between Betts v. Brady and White v. Ragen.

It would be unwise to overlook the fact that men under long penitentiary sentences, with abundant opportunity for reflection on how to get out, may imagine or invent all sorts of spurious claims concerning the denial of the right to counsel. Undoubtedly, petitions for habeas corpusspurred on by Supreme Court decisions-can reach epidemic proportions and thus create serious problems in the administration of state criminal law. Yet it is possible to sift the spurious petitions from the genuine only by affording hearings broad enough to allow controverted issues of fact to be developed.

The states have at their disposal three simple but effective means of protecting themselves and at the same time safeguarding the interests of a defendant:

I. The relatively small group of states which have not already done so should adopt a broad rule concerning the assignment of counsel, at least in felony cases. Rule 44 of the newly-adopted Federal Rules of Criminal Procedure might well serve as a model:

If the defendant appears in court without counsel, the court shall advise him of his right to counsel and assign counsel to represent him at every stage of the proceedings unless he elects to proceed without counsel or is able to obtain counsel.

The rule, of course, would carry the states considerably beyond their obligation under the Fourteenth Amendment as construed in the Betts case. But no state can take pride in holding its trials down to the bare minimum of fairness required by the Fourteenth Amendment. Compliance with Rule 44 would assure that no man, merely because of poverty or igno- 
rance, went to trial on a serious charge without the opportunity to obtain legal assistance.

2. Criminal courts must be encouraged to keep careful records concerning the defendant's right to counsel. If an attorney appeared on the defendant's behalf, his name should be specified in the record. If the defendant came to court without an attorney, the record should show (a) wheth$\mathrm{er}$, in what terms, and at what stage of the proceedings, the court notified the defendant of his right to counsel, (b) the name of any attorney appointed by the court and the stage of the proceedings at which the appointment was made, and (c) the specific reason (such as an express and intelligent waiver) for any failure of the court to appoint an attorney. Meticulous records are harder to keep than sloppy ones, but they are not readily impeached and constitute firm evidence long after men's recollections have dimmed.

3. In the handling of collateral attacks on judgments of conviction, state courts should be encouraged-either by rules of practice or by admonitions at judicial conferences-to specify the ground of decision when a petition is denied without hearing. Many petitions which suffer from the vagueness exemplified by the petition in the Tomkins case could properly be rejected by the state court on the ground of indefiniteness, at least if leave to plead over were granted. A clear statement of the ground of decision would make it easier for state courts to shape their own rules of pleading and proof in such cases, without giving the appearance of denying on the merits the federal right asserted.

\section{NEGRO EXCLUSION}

Between the Civil War and the Scottsboro cases the Supreme Court reversed only four state court convictions-the last in I904-on the ground of systematic exclusion of Negroes from jury service..$^{22}$ But there have already been five such reversals since the Scottsboro cases. These have included cases where the bar to Negroes from jury service had been long continued and complete. In Hale v. Kentucky ${ }^{43}$ no Negroes had even been summoned

${ }^{42}$ Rogers v. Alabama, I92 U.S. 226 (I904); Carter v. Texas, I77 U.S. 442 (I900); Neal v. Delaware, I03 U.S. 370 (I88I); Strauder v. West Virginia, I00 U.S. 303 (I880). The Carter case provides an unusual illustration of the benefits which a defendant may obtain by delay. Carter originally had been sentenced to death for first-degree murder. Some of the state's witnesses were drowned in the Galveston storm of September 8, 1900, and at the retrial which followed the reversal Carter pleaded guilty to second-degree murder and the jury directed a five-year sentence. Galveston Daily News, November I4, Igor.

${ }^{43} 303$ U.S. 6r3 (1938). Hale, a Negro, had been sentenced to death for murdering a white man; on the remand the case was settled by a compromise agreement under which Hale pleaded guilty and received a sentence of life imprisonment. Louisville Courier-Journal, April 30, 1939. 
for service on a grand or petit jury in McCracken County for thirty years, excepting a single occasion in r92I when no Negro was actually selected. In Hollins v. Oklahoma, ${ }^{44}$ no Negro had served on a jury in Okmulgee County since Oklahoma's admission to statehood in 1907, although the testimony indicated that one Negro might have been called around rgro. Similarly in Hill v. Texas, ${ }^{45}$ no Negro had been placed on a grand jury list in Dallas County for sixteen years or more. Pierre v. Louisiana ${ }^{46}$ disclosed that no Negro had served on a grand or petit jury in St. John the Baptist Parish for forty years; and while three Negroes were listed on the venire from which the grand jury had been selected, one of them was dead and another incorrectly identified because his name was misspelled. The discrimination was slightly more subtle in Smith v. Texas. ${ }^{47}$ Negroes were called for grand jury duty in Harris County but almost invariably they were assigned number I6-a number not reached unless it was impossible to obtain the required jurors from the first fifteen names on the list; as a result no Negroes had served on a grand jury during 1937 and.1938, and not more than one or two per year from I93 I to I936. In all five cases it appeared that qualified Negroes were available, and in all the Supreme Court unhesitatingly upset the judgments.

The subsequent proceedings in the Pierre case illustrate the steps which a state court may take to accommodate its practices to the Constitution. After the reversal Pierre, who originally had been sentenced to death for murdering an aged constable of the parish, was reindicted on three sepa-

44295 U.S. 394 (I935). Hollins, an illiterate negro, originally had been sentenced to death after pleading guilty, in December, I931, to raping a seventeen-year-old white girl, but the Oklahoma Criminal Court of Appeals set aside the conviction on the ground that his right to counsel had not been adequately safeguarded. Ex parte Hollins, 5I Okla. Cr. 70, 14 P. 2d 243 (1932). After his death sentence was reversed by the Supreme Court, Hollins was retried in February, 1936; the jury found him guilty but fixed the punishment at life imprisonment, adding a gratuitous recommendation that the sentence be carried out "without pardon or parole."

453 I6 U.S. 400 (I942). The reversal had a curious sequel. Less than a year after the crime was committed, and while Hill's appeal had been pending in the state court, Texas enacted a law remedying the situation mentioned in note 47 , infra, by permitting reindictment after the year had run. Hill was reindicted more than a year after the crime, and contended that the legislation was ex post facto as to him. The Texas Court of Criminal Appeals thought otherwise, and affirmed a death sentence; Hill died of acute appendicitis while his petition for certiorari was pending. Hill v. State, I46 Tex. Cr. App. 333, I7 S.W. $2 d 880$ (I943), petition for cert. dismissed, 320 U.S. 806 (1943).

${ }^{46} 306$ U.S. 354 (1939).

${ }^{47} 3$ II U.S. I 28 (I940). After the reversal Smith became the beneficiary of a Texas one-year statute of limitations on rape prosecutions, which neglected to provide for reindictment more than a year after the crime in the event that an original timely reindictment was upset as invalid. He was accordingly released from custody, and his counsel announced he was being hurried out of the county to forestall any attempt at mob violence. Houston Post, January I8, I94r. 
rate occasions. One indictment the trial judge quashed because a grand juror was disqualified by illiteracy; another, because he thought the testimony of two jury commissioners might be construed to show a prejudice against selecting Negroes. The judge appointed three new commissioners, who submitted 300 names-including fifty-two Negroesfor the list from which the grand and petit juries were to be drawn. As a result, five Negroes were on the grand jury panel of twenty, and two served on the grand jury of twelve that returned the final indictment. A petit jury was obtained after examination of $I$ IO persons, of whom ninety-five were white and fifteen Negro. One of the petit jurors was a Negro, and another Negro was acceptable to the state but was challenged by Pierre. The Louisiana Supreme Court affirmed a new conviction, finding in the record no proof of Negro exclusion. ${ }^{8}$ Certiorari was denied, ${ }^{49}$ and, after some further dilatory moves, ${ }^{50}$ Pierre was executed in Louisiana's portable electric chair. ${ }^{5 x}$

In the Hill case the Supreme Court observed that "discrimination can arise from the action of commissioners who exclude all negroes whom they do not know to be qualified and who neither know nor seek to learn whether there are in fact any qualified to serve." 52 Dallas County's effort to mend its ways consisted of placing on the grand jury list at the October, I942, term one Negro who did not serve, and on the grand jury list at the January, I943, term one Negro who did serve. Akins v. Texas, ${ }^{53}$ challenging an indictment returned at the latter term, presented the question whether the reform had been sufficient. Akins contended that the jury commissioners had deliberately limited to one the number of Negroes in the list, merely to give an appearance of Negro representation. The Supreme Court, three justices dissenting, nevertheless sustained the conviction. With what may seem undue generosity to the jury commissioners in the light of their quoted testimony, the Court held that the record fell short of providing clear proof of a deliberate limitation of the number of negroes. Accordingly, the opinion found it unnecessary to decide whether the Fourteenth Amendment prohibits deliberate limitation of Negro jurors to the approximate proportion that the number of eligible Negroes

${ }^{4}$ State v. Pierre, I98 La. 619, 3 So. 2d 895 (I94I).

19 Pierre v. Louisiana, 314 U.S. 676 (I94I).

so State ex rel. Pierre v. Jones, 200 La. 808, 9 So. 2 d 42 (I942), cert. denied, 3 I 7 U.S. 633 (1942).

sx New Orleans Times-Picayune, January 31, 1943.

52316 U.S. 400, 404 (1942).

${ }^{53} 325$ U.S. $39^{8}$ (1945). 
bears to the total number of persons eligible (in Dallas County about I 5 per cent of the population is Negro).

The extent to which Negroes are being denied representation on juries can, of course, hardly be gauged from a handful of litigated cases, each involving but a single county or judicial district. There is an evident need for more comprehensive surveys, state by state, which will inquire into the practical working of the jury system.

\section{COERCED CONFESSIONS}

Of relatively recent development has been the doctrine that the Due Process Clause of the Fourteenth Amendment invalidates state court convictions founded on confessions not the product of reasoned choice. While a federal conviction involving the use of a defendant's involuntary statement was reversed as early as 1897,54 it was not until I936 that the Supreme Court had before it, in Broven v. Mississippi, ${ }^{55}$ the question "whether convictions, which rest solely upon confessions shown to have been extorted by officers of the state by brutality and violence, are consistent with the due process of law required by the Fourteenth Amendment." Beginning with that case the Supreme Court has rendered twelve decisions involving assertedly coerced confessions introduced in state court proceedings; the Court has ordered reversals in ten cases (in eight of them unanimously) and affirmances (each time by a divided court) in the other two.

The three defendants in Brown v. Mississippi were Nègroes sentenced to death for murdering a white man. Their convictions were based on confessions which the undisputed evidence revealed were produced by beatings, in the course of which the backs of two defendants were cut to ribbons, and by whipping the other defendant and hanging him to a tree. In the words of the dissenting opinion in the Supreme Court of Mississippi, "the transcript reads more like pages torn from some medieval account than a record made within the confines of a modern civilization which aspires to an enlightened constitutional government." ${ }_{56}^{6}$ The Supreme Court of the United States reversed, saying uncompromisingly:

54 Bram v. United States, $x 68$ U.S. 532 (I897). The basis for the decision was the provision of the Fifth Amendment that "no person .... shall be compelled in any Criminal Case to be a witness against himself." For other cases discussing the admissibility of confessions in federal court proceedings see United States v. Mitchell, 322 U.S. 65 (I944); Anderson v. United States, 3 I8 U.S. $35^{\circ}$ (r943); McNabb v. United States, 3 I8 U.S. 332 (I943); Wan v. United States, 266 U.S. I (I924); Wilson v. United States, I62 U.S. 6I3 (I896); Pierce v. United States, I60 U.S. 355 (I896); Sparf and Hansen v. United States, I56 U.S. 5 I (I895); Hopt v. Utah, I IO U.S. 574 (1884); see also note 70 , infra.

55 297 U.S. 278 (1936).

${ }^{56}$ I73 Miss. 542, 574, I6r So. 465,470 (I935). 
It would be difficult to conceive of methods more revolting to the sense of justice than those taken to procure the confessions of these petitioners, and the use of the confessions thus obtained as the basis for conviction and sentence was a clear denial of due process. 57

Chambers v. Florida ${ }^{58}$ required the Supreme Court to turn from considering the effects of leather straps on the will of an accused, and to appraise the subtler influence of protracted interrogation under circumstances conducive to terror. The defendants, Isiah Chambers, Jack Williamson, Charlie Davis, and Walter Woodward, were among about forty Negroes arrested without warrant and confined within twenty-four hours after the murder of an elderly white fish-dealer on Saturday, May I3, I933. All were subjected to questioning from Sunday, May. I4, to Saturday, May 20. From the afternoon of the 2oth until sunrise of the 21st, the four defendants, and possibly one or two others, singly underwent persistent and repeated questioning. Woodward "broke" at about $2: 30$ A.M. Sunday morning; the state's attorney was not satisfied with the "confession," however, and the grilling was resumed until just before sunrise, when all four defendants made satisfactory "confessions." The evidence was conflicting as to whether the petitioners were continually threatened and mistreated. They apparently were accorded no opportunity to see friends or relatives or to consult counsel. Indictment and arraignment for murder followed. Williamson and Woodward pleaded guilty and asked the mercy of the court. Davis did likewise after withdrawing his original plea of not guilty. Chambers pleaded not guilty and was convicted by a jury on the basis of his confession and the testimony of his co-defendants. Sentences of death were imposed on all four. After the case completed a tortuous course through the courts of Florida, ${ }^{59}$ it

57 Brown v. Mississippi, 297 U.S. 278,286 (1936). After the reversal the case was settled by a compromise. The three defendants pleaded nolo contendere to a charge of manslaughter; Brown was sentenced to seven and a half years' imprisonment, Shields to two and a half, and Ellington to three with credit for the two and a half years he had already served. Jackson (Miss.) Daily Clarion Ledger, November 29, I936; ibid., December I, 1936.

${ }^{88} 309$ U.S. 227 (I940).

59 In August, I933, the defendants filed a petition for habeas corpus in the Supreme Court of Florida, which refused to entertain the petition, issuing instead a writ of error to the Broward County Circuit Court where the judgments had been entered. The defendants' counsel defaulted, and the Supreme Court of Florida affirmed the convictions, stating that, upon its own examination of the record, it found no error. Chambers v. Florida, III Fla. 707, 15I So. 499 (1933). There was then filed in that court a petition for writ of error coram nobis, which alleged in detail, and for the first time, that the confessions had been improperly extorted, that the testimony of Chambers' three co-defendants had been given at his trial under duress, and that appointed counsel had made no effort to prepare the case or to inquire into facts which should have been brought to the attention of the trial court. The Florida Supreme Court held that those allegations, if true, would establish the unfairness of the trial; it therefore granted leave, as is the Florida practice, to present the petition to the trial court. III Fla. 7I2, II3 Fla. 786, 
reached the Supreme Court on certiorari. The Supreme Court's opinion held, first, that-even though the issue of the confessions had been passed on by the jury-it was the duty of the Supreme Court to determine, by independently reviewing the facts on which the issue turned, whether the confessions were obtained by means proscribed by the Due Process Clause. $^{60}$ The Court then placed its reversal of the judgment on the following grounds:

For five days petitioners were subject to interrogations culminating in Saturday's (May 2oth) all night examination. Over a period of five days they steadily refused to confess and disclaimed any guilt. The very circumstances surrounding their confinement and their questioning without any formal charges having been brought, were such as to fill petitioners with terror and frightful misgivings. Some were practical strangers in the community; three were arrested in a one-room farm tenant house which was their home; the haunting fear of mob violence was around them in an atmosphere charged with excitement and public indignation. From virtually the moment of their arrest until their eventual confessions, they never knew just when any one would be called back to the fourth floor room, and there, surrounded by his accusers and others, interrogated by men who held their very lives-so far as these ignorant petitioners could know-in the balance. The rejection of petitioner Woodward's first "confession," given in the early hours of Sunday morning, because it was found wanting, demonstrates the relentless tenacity which "broke" petitioners' will and rendered them helpless to resist their accusers further. To permit human lives to be forfeited upon confessions thus obtained would make of the constitutional requirement of due process of law a meaningless symbol. ${ }^{6 x}$

Seven full years of litigation, during which Chambers had been transferred to a state hospital for the insane at Chattahoochee, thus left the cause remanded for retrial. Subsequent proceedings brought the release of Williamson, Davis, and Woodward, after their long sojourn in the death house. $^{62}$

I52 So. 437 (1934). The Broward County court denied the ensuing application without taking evidence, on the ground that in its opinion the allegations were false, but the Florida Supreme Court reversed, directing that the issues be tried before a jury. II 7 Fla. 642, I5 8 So. I 53 (I934). Upon a jury verdict adverse to the defendants, the trial court again imposed death sentences; appeal brought another reversal, for misinstruction of the jury. 123 Fla. 734, I67 So. 697 (I936). Upon a change of venue to Palm Beach County, a new jury found against the defendants, and this time sentences of death were sustained by the Florida Supreme Court. 136 Fla. 568, 187 So. 156 (1939).

${ }^{60}$ This followed the principle established in cases involving discrimination in the selection of juries. See pp. 279-82, supra.

6r 309 U.S. 227, 239-40 (I940).

${ }_{62}$ On the remand the Palm Beach County court on December II, 1940, quashed the I933 indictment on the ground that Negroes had been systematically excluded from the grand jury. The four defendants were reindicted in Broward County on March II, I94I. Williamson, Davis, and Woodward sought to avoid retrial by an application to the Florida Supreme Court for habeas corpus, which was denied. Williamson v. Baker, I48 Fla. 387, 4 So. 2d $47 \mathrm{I}$ (194I). By a change of venue, the case was again brought to Palm Beach County, where, on March 9, 1942, the retrial of Williamson, Davis, and Woodward finally took place. Williamson 
During the same and the following term of Court four more capital cases, all from the South and involving Negro defendants from whom confessions were wrung under somewhat similar circumstances, were reversed per curiam. In the first of these, Canty v. Alabama, ${ }^{63}$ the record showed that after being arrested Canty (laying aside his disputed claim that he was beaten) was kept in the dark basement "doghouse" of the jail, which had whipping straps hanging on the wall, for an entire week, during which he was taken out for intermittent questioning; and his confession of murdering a white woman, given at the end of a week of such treatment, was immediately preceded by six hours of continuous questioning. In Vernon v. Alabama, ${ }^{64}$ the defendant was held for twelve days between his arrest and confession of murder, with no opportunity to consult counsel. Police officials admitted taking him out to the woods and other lonely places on four or five occasions in the dead of night for some kind of questioningaccording to Vernon, for severe beatings; according to the police, to hunt for watches Vernon was supposed to have stolen from hoboes. Lomax $\mathrm{v}$. Texas ${ }^{65}$ disclosed that, on the morning of his arrest on a charge of raping a white woman, Lomax had been stripped naked while he was being questioned; and that night, during the several hours of continuous questioning which led up to his confession, he was never allowed to sit down.

In the fourth of the per curiam reversals, White v. Texas, ${ }^{66}$ the state au-

and Woodward sought to plead guilty to second-degree murder, but the trial judge refused to receive their pleas when he learned by questioning that they wanted to accept prison sentences "just to get it over with." The state called eight witnesses, but without the extorted confessions was unable to make out a case. The judge directed verdicts of acquittal. See Jacksonville (Fla.) Times-Union, March Io, 1942.

${ }^{63} 309$ U.S. 629 (1940). On retrial, without the confession, Canty was again convicted, receiving a sentence of life imprisonment instead of death, but he won a reversal because of a prejudicial instruction. Canty v. State, $242 \mathrm{Ala} .589,7$ So. $2 \mathrm{~d} 292$ (1942). A third jury then found him guilty, again setting the penalty at life imprisonment. This conviction was affirmed, 244 Ala. 108, I I So. 2d 844 (1943), cert. denied, 319 U.S. 746 (1943).

${ }^{64} 313$ U.S. 547 (I94I). See Boskey, Mechanics of the Supreme Court's Certiorari Jurisdiction, $46 \mathrm{Col}$. L. Rev. 255, 263-64 (I946). On retrial, without the confession, Vernon was again convicted and sentenced to death. In affirming, the Supreme Court of Alabama refused, because no proper bill of exceptions had been drawn on those questions, to pass on two attacks against the indictment. Vernon claimed that ( $\mathrm{r}$ ) Negroes had been excluded from the grand jury, and (2) the only evidence before the grand jury had been the extorted confession. Vernon v. State, 245 Ala. 633 , I8 So. 2 d 388 (1944).

${ }^{65} 3^{1} 3$ U.S. 544 (I94I). Lomax's first conviction had been upset by the state court because the trial judge had neglected to submit to the jury the question whether the confession was voluntary. Lomax v. State, 136 Tex. Cr. App. 108, I24 S.W. 2d I26 (I939). After the Supreme Court's decision, Lomax's third trial, without benefit of the tainted confession, resulted in a sentence of life imprisonment which was upheld by the Texas Court of Criminal Appeals. I46 Tex. Cr. App. 53r, I76 S.W. 2d 752 (rg44).

${ }^{66}{ }_{309}$ U.S. 63I, 3 I0 U.S. 530 (1940), reversing White's second conviction. White's first conviction had been reversed by the state court because of the prejudicial conduct of the 
thorities had the bad judgment to ask for a rehearing, which produced only an opinion detailing the shocking circumstances under which White's purported confession had been obtained. White, an illiterate Negro, was one of about fifteen Negroes taken into custody, without the filing of charges, in connection with the rape of a white woman. He was kept in jail for six or seven days during which, he testified, Texas Rangers took him out into the woods on successive nights and whipped him. The Texas authorities denied that White had been physically mistreated, but there were no specific denials that he had been taken out of jail, at night, and interrogated in the woods. His "confession." followed a final four hours of persistent questioning, from II:00 P.M. to 3:00 A.M. He had no lawyer, no charges had been filed against him, and he was out of touch with friends and relatives.

Although White's confession was the crux of the state's case, he did not long enjoy the benefits of the reversal. While a jury was being empanelled for his third trial, White was shot and killed in open court by W. S. Cochran. Cochran was the husband of the prosecutrix-a position which apparently led him to believe that he was a higher tribunal than the Supreme Court. ${ }^{67}$

The first affirmance (and the first division on the part of the Court) in this series of cases came in Lisenba v. California ${ }^{68}$ where the Court refused to read into the Due Process Clause an absolute rule excluding a confession merely because state authorities have committed serious il-

prosecuting attorney, who had stated in his summation to the jury: "Look at this court-room: it is crowded with Polk County people demanding the death penalty for Bob White." White v. State, I35 Tex. Cr. App. 210, II7 S.W. 2d 540 (1938).

${ }^{67}$ After the shooting, several persons are reported to have shaken hands with Cochran, who immediately surrendered himself into custody. Houston Post, June II, I94I. Cochran was indicted for murder and tried June 16 , I94I. The testimony showed that he had been informed by the special prosecutor that White could never be convicted without the confession. Cochran himself testified that he had sat down in the courtroom, "then I got up and the next thing I know the negro was dead." The district attorney conducting the prosecution of Cochran told the jury: "When the case was reversed it looked like the end of the row as far as the law was concerned. The state proceeded to trial again last week, knowing it would not have the use or benefit of White's signed confession. The state's case would have to be based on circumstances which without the confession would have been insufficient to sustain a conviction. It was unfortunate that Mr. Cochran was forced to do that which was done. It was his wish that the law handle the matter. In my opinion the guilty party got justice, but it was unfortunate that it had to be at Mr. Cochran's hands. . . . . If I were going into that jury room, I wouldn't hesitate, I wouldn't stand back a minute, in writing a verdict of not guilty. . . . I ask you to return a verdict finding Mr. Cochran not guilty." Applause, it is reported, began during this spirited statement on behalf of the prosecution. The anticipated verdict of not guilty set off an impromptu celebration of cheering and whistling. Houston Post, June r7, r94r.

${ }^{68} 3 \mathrm{I}_{4}$ U.S. $2 \mathrm{I}_{9}$ (I94I). This was on reargument; on the original argument the judgment was affirmed by an evenly divided court. $3^{\text {I } 3}$ U.S. 537 (I94I). 
legal acts against the defendant in the course of obtaining it. Lisenba was arrested on Sunday, April I9, I936, and taken to the house adjoining his, where he was held incommunicado and questioned about the death of his wife through the morning of April 2I, without result. He was then arraigned, jailed, and allowed to consult his attorney. On the afternoon of Saturday, May 2, he was removed from jail under a purported court order and confronted with the statement of an alleged accomplice incriminating him in the murder of his wife. A request for consultation with his attorney brought the information that the attorney was out of town; a subsequent request for opportunity to consult any other attorney was denied. After persistent questioning into the early hours of May 3, Lisenba confessed. The Supreme Court pointed out, (I) that the failure of the arresting officers promptly to produce Lisenba before an examining magistrate and their detention of him from April I9 through April 2I were violations of state statutes, (2) that no authority was found for the purported court order of removal on May 2, and (3) that the denial of the opportunity to consult counsel was a misdemeanor. The Court concluded, however, that: illegal acts, as such, committed in the course of obtaining a confession, whatever their effect on its admissibility under local law, do not furnish an answer to the constitutional question we must decide. The effect of the officers' conduct must be appraised by other considerations in determining whether the use of the confessions was a denial of due process. ${ }^{69}$

With respect to federal criminal proceedings (as distinguished from those of the states) the $M c N a b b$ and $A n d e r s o n^{70}$ decisions were soon to make clear, however, that, regardless of constitutional considerations, the Supreme Court in supervising the administration of criminal justice in the federal courts will not permit the use in evidence of confessions obtained while suspects are held incommunicado in violation of statutory requirements for prompt examination or arraignment.

In the Lisenba case, the Supreme Court again affirmed its duty to make an independent review of the record to determine the validity of the federal claim asserted. But, as often happens in close cases where the Court declines to upset a state judgment, ${ }^{71}$ the opinion placed great stress on the deference to be paid to the state court's determination, stating that when there is conflicting evidence on the methods used to obtain a confession,

${ }^{69}$ Ibid., at 235 .

70 McNabb v. United States, 3 I8 U.S. 332 (Ig43); Anderson v. United States, 318 U.S. 350 (r943). Compare United States v. Mitchell, 322 U.S. 65 (I944), holding that a confession made immediately after an accused was taken into custody was not rendered inadmissible by subsequent illegal detention.

${ }^{7 x}$ See, e.g., Akins v. Texas, 325 U.S. 398 (x945), discussed at p. 28r, supra. 
we accept the determination of the triers of fact, unless it is so lacking in support in the evidence that to give it effect would work that fundamental unfairness which is at war with due process. ${ }^{72}$

The earlier confession cases were distinguished as involving graver circumstances, that is, as cases where the confessions had been secured by

protracted and repeated questioning of ignorant and untutored persons in whose minds the power of officers was greatly magnified; who sensed the adverse sentiment of the community and the danger of mob violence; who had been held incommunicado, without the advice of friends or of counsel; some of whom had been taken by officers at night from the prison into dark and lonely places for questioning. ${ }^{73}$

Although the Supreme Court voiced its disapproval of the violations of law involved in the treatment of Lisenba, it concluded:

But on the facts as we have endeavored fairly to set them forth, and in the light of the findings of the state courts, we cannot hold that the illegal conduct in which the law enforcement officers of California indulged, by the prolonged questioning of the prisoner before arraignment, and in the absence of counsel, or their questioning on May 2, coerced the confessions. . . . .74

Two justices dissented on the ground that Lisenba's confession was clearly shown to have been coerced.

While Lisenba's case held that illegal acts committed by state authorities in the course of securing a confession do not of themselves make the confession inadmissible under the Due Process Clause, the Supreme Court found in Ward v. Texas s $^{75}$ that such acts indicated the involuntary nature of Ward's "confession." Ward, a Negro, had received a three-year sentence for murdering a white man without malice. The conviction rested on his confession. The Texas Court of Criminal Appeals at first reversed, but on rehearing reinstated the judgment in deference to the jury's decision that the confession was voluntary. The Supreme Court of the United States accepted the jury's verdict as conclusively resolving, in the state's favor, the conflicting evidence respecting Ward's assertion that he had been beaten, whipped, and burned. The Court nevertheless denied effect to the jury's conclusion that the confession was voluntary, since the undisputed evidence showed that (I) Ward was questioned, but not taken into custody, on the Sunday and Monday following the homicide; (2) the next night, Tuesday, Ward was seized without warrant by a sheriff from an adjoining county and taken in the course of the ensuing three days through five counties, spending each night in a different jail, until his journey ended one hundred and ten miles from his home; and (3) during

72 Lisenba v. California, 3r4 U.S. 219, 238 (I94I).

73 Tbid., at $239-40$.

74 Tbid., at 240.

${ }^{75} 316$ U.S. 547 (I942). 
that period Ward was questioned continually until, in the revealing words of one officer, the authorities "just sweet talked" the confession out of him. In holding that the Due Process Clause required the exclusion of Ward's confession, the Supreme Court stressed the fact that the Texas officials acted illegally from the beginning until the end of Ward's journey into fear. The Court found unconvincing the state's assertion that the hegira was undertaken because of fear of mob violence, without any intent to coerce a confession. ${ }^{76}$

In Ashcraft v. Tennessee" the Supreme Court found "inherently coercive" a situation in which Ashcraft, after being questioned without respite for a period of thirty-six hours (extending from Saturday night to Monday morning), was alleged to have made a written, unsigned confession. Ashcraft, together with a Negro named Ware, had been tried jointly for the murder of Ashcraft's wife (which occurred in June, I94I), on the theory that Ashcraft hired Ware to do the murder; they were convicted and each sentenced to ninety-nine years. In reversing Ashcraft's conviction, the Supreme Court said:

Our conclusion is that if Ashcraft made a confession it was not voluntary but compelled. We reach this conclusion from facts which are not in dispute at all. Ashcraft, a citizen of excellent reputation, was taken into custody by police officers. Ten days' examination of the Ashcrafts' maid, and of several others, in jail where they were held, had revealed nothing whatever against Ashcraft. Inquiries among his neighbors and business associates likewise had failed to unearth one single tangible clue pointing to his guilt. For thirty-six hours after Ashcraft's seizure during which period he was held incommunicado, without sleep or rest, relays of officers, experienced investigators, and highly trained lawyers questioned him without respite. From the beginning of the questioning at 7 a'clock on Saturday evening until 6 o'clock on Monday morning Ashcraft denied that he had anything to do with the murder of his wife. And at a hearing before a magistrate about 8:30 Monday morning Ashcraft pleaded not guilty to the charge of murder which the officers had sought to make him confess during the previous thirty-six hours. ${ }^{8}$

This brought the Court to its conclusion:

We think a situation such as that shown here by uncontradicted evidence is so inherently coercive that its very existence is irreconcilable with the possession of mental freedom by a lone suspect against whom its full coercive effect is brought to bear. It is inconceivable that any court of justice in the land, conducted as our courts are, open to the public, would permit prosecutors serving in relays to keep a defendant witness under continuous cross-examination for thirty-six hours without rest or sleep in an effort to extract a "voluntary" confession. Nor can we, consistently with Constitutional due process of law, hold voluntary a confession where prosecutors do the same thing away from the restraining influences of a public trial in an open court room. 79

${ }^{76}$ When the case was remanded, it was dismissed, on October 22,1942 , at the request of the district attorney.

${ }^{77} 322$ U.S. 543 (1944). $\quad{ }^{88}$ Ibid., at I $_{53} . \quad{ }^{9}$ Ibid., at 154. 
The Supreme Court found it unnecessary to resolve conflicting evidence as to whether (I) violence had been used, and (2) Ashcraft had actually confessed. On the latter point the Court followed White v. Texas ${ }^{80}$ in ruling that the use of a coerced confession cannot be justified on the ground that the defendant denies that he actually made the confession. Justices Jackson, Roberts, and Frankfurter, in dissent, expressed concern that the Court's decision unduly interfered with the law enforcement powers of the states. Violence per se, they agreed, was enough to invalidate a resulting confession, but interrogation per se-even when continued without interruption for thirty-six hours-was not.

The state court had affirmed Ware's conviction on the assumption that Ashcraft's confession was properly admitted and Ashcraft's conviction valid. The Supreme Court, following a suggestion by counsel for the state, accordingly vacated the judgment as to Ware, remanding his case for reconsideration in the light of the rejection of Ashcraft's confession. The Tennessee Supreme Court directed that Ware, too, be given a new trial. At that trial the state, although precluded from introducing the alleged confession which had climaxed the thirty-six hours of interrogation, was permitted to parade before the jury testimony narrating everything else that took place during the entire thirty-six hours. This evidence was highly prejudicial to the defense. For the first twenty-eight hours Ashcraft had consistently denied both his own complicity in the crime and any knowledge of the murderer's identity; however, at the end of twentyeight hours of continuous questioning his inquisitors had elicited a damaging statement that he knew who killed his wife, although he denied having participated in the murder himself. Despite the circumstances under which his statements were obtained, the Tennessee Supreme Court affirmed life sentences meted out to both defendants. The Supreme Court of the United States a second time reversed, finding no relevant difference from the case as previously before it. ${ }^{8 x}$ And the Court again followed the state's suggestion that, if Ashcraft's conviction were upset, the judgment as to Ware should be vacated. Thus in neither case was the Court required to decide on the constitutionality of admitting into evidence a controverted confession made by Ware.

Lyons v. Oklahoma ${ }^{82}$ involved the question whether a confession was inadmissible because a previous confession, which was not put in evidence, had been coerced. Lyons, a Negro, was sentenced to life imprisonment for

\footnotetext{
${ }^{80}$ 310 U.S. 530, 531-32 (1940).

${ }^{81}$ Ashcraft v. Tennessee, 66 Sup. Ct. 544 (I946).

${ }^{82} 322$ U.S. 596 (I944).
} 
a triple murder. He had first confessed orally after being questioned from 6:30 P.M. until between 2:00 and 4:00 A.M. under circumstances which included the macabre touch of placing a pan of the victims' bones in his lap. That oral confession, however, was not used at his trial. He was returned to jail at 8:30 the same morning and taken in the afternoon to the penitentiary where between 8:00 and II:00 that evening he gave a signed confession to the warden. This second confession was submitted to the jury under instructions to disregard it, if they found it had been obtained by punishment, intimidation, or threats; instructions requested by Lyons covering his contention that the second confession sprang from fear engendered by his previous treatment were not given. The Oklahoma Criminal Court of Appeals affirmed, and the Supreme Court of the United States, three justices dissenting, did likewise. The Supreme Court's opinion, citing the Lisenba decision, pointed out that if the jury believed the warden and other witnesses for the state, the only ground for reversal would be the theory that Lyons' second confession was the unavoidable outgrowth of his first. While acknowledging that earlier coercion is a factor which in certain circumstances may compel the inference that a subsequent confession was coerced, the Court continued:

If the relation between the earlier and later confession is not so close that one must say the facts of one control the character of the other, the inference is one for the triers of fact and their conclusion, in such an uncertain situation, that the confession should be admitted as voluntary, cannot be a denial of due process. ${ }^{83}$

The Court concluded that the evidence clearly warranted the jury's determination that the effects of the prior coercion had been dissipated in the period of less than twenty-four hours which separated Lyons' two confessions. It thus avoided approving or disapproving Lyons' claim that earlier abuses should be presumed to render a subsequent confession involuntary unless there is clear and definite evidence to overcome that presumption. Mr. Justice Douglas concurred in the result. Justices Murphy and Black urged in dissent that (I) it was inconceivable under the circumstances that Lyons' second confession was free from the coercive atmosphere that admittedly impregnated his first one, and (2) the jury had not resolved the issue of coercion because the instruction on the point requested by Lyons had not been given. Mr. Justice Rutledge also dissented.

The next case in the series, Malinski v. New York, ${ }^{84}$ produced even more divergent views - a divergence springing at least in part from the slovenliness of the complex record which had been made in the state

$$
8_{3} \text { Ibid., at } 603 \text {. } \quad{ }_{4}^{8} 324 \text { U.S. } 40 \text { I (I945). }
$$


courts. The petitioners, Morris Malinski and Sidney Rudish, were convicted and sentenced to death for the murder of a police officer; the New York Court of Appeals, by a vote of four to three, affirmed. The facts relevant to Malinski's confession, as set forth in the opinion of the Supreme Court, were:

Malinski was arrested while on his way to work on the morning of Friday, October 23, 1942. The police did not then arraign him but took him to a room in the Bossert Hotel in Brooklyn where he arrived about 8 A.M. He was immediately stripped and kept naked until about II A.M. At that time he was allowed to put on his shoes, socks and underwear and was given a blanket in which to wrap himself. He remained that way until about 6 P.Mr. Malinski claims he was beaten by the police during that period. The police denied this. There was no visible sign of any beating, such as bruises or scars; and Malinski made no complaint to the judge on arraignment nor to the jail authorities where he was later held. Sometime during Friday morning Spielfogel [an informer who was a friend of Malinski] was brought to the hotel. He and Malinski were put alone together in a room sometime that afternoon. Shortly after their conferenceapparently around 5:30 P.M. or 6:00 P.M.-Malinski confessed to the police. ${ }^{85}$

After making this first confession, Malinski was allowed to dress. He was kept at the hotel for the next three days, while he was questioned intermittently and made certain admissions; and at about $2: 00$ A.M. on October 27 he made another confession at a police station. He was then booked, put in a cell, and arraigned. In reversing Malinski's conviction, the opinion of the Court by Mr. Justice Douglas-with whom Justices Black, Murphy, and Rutledge concurred so far as Malinski was concerned-concluded that, in addition to strong indications from the evidence that Malinski's first confession was coerced, "the comments of the prosecutor place it beyond doubt."

For in his summation to the jury he made certain statements which the Court of Appeals said were "indefensible". . . and which we think are sufficient to fill in any gaps on the record before us and to establish that this confession was not made voluntarily. He said that Malinski "was not hard to break"; that "He did not care what he did. He knew the cops were going to break him down." And he added "Why this talk about being undressed? Of course they had a right to undress him to look for bullet scars, and keep the clothes off him. That was quite proper police procedure. That is some more psychology - let him sit around with a blanket on him, humiliate him there for a while; let him sit in the corner, let him think he is going to get a shellacking." If we take the prosecutor at his word, the confession of October 23rd was the product of fear-one on which we could not permit a person to stand convicted for a crime. ${ }^{86}$

The Court found that, while the details of Malinski's first confession were not put in evidence, the record showed that such use had been made of it at the trial that the case had to be considered "as one in which a coerced confession was employed to obtain a conviction." Lyons v. Oklahoma was

85 Tbid., at 403 .

${ }^{86}$ Ibid., at 406-7. 
distinguished on the ground that there the first coerced confession was considered only in so far as it shed light on the voluntary nature of subsequent confessions. The opinion did not expressly pass on the admissibility of Malinski's later admissions and confession. Concurring separately, Mr. Justice Frankfurter noted that the circumstances surrounding Malinski's conviction "in combination are so below the standards by which the criminal law, especially in a capital case, should be enforced as to fall short of due process of law."

The Court refused to vacate the judgment against Rudish, holding that the trial court had taken effective steps to insulate him from the effects of Malinski's confessions, and that under the circumstances the Due Process Clause did not require the procedure followed in vacating Ware's conviction in the Ashcraft case.

Mr. Justice Rutledge, dissenting in part in an opinion which had $\mathrm{Mr}$. Justice Murphy's support, took the view that (I) Malinski's subsequent confessions were "vitiated with all the coercion that destroys the admissibility of the first one," and (2) the use of Malinski's confessions so affected the trial of Rudish as to require a reversal of Rudish's conviction. Mr. Justice Murphy also filed an opinion along similar lines, and urged that:

Once an atmosphere of coercion or fear is created, subsequent confessions should automatically be invalidated unless there is proof beyond all reasonable doubt that such an atmosphere has been dispelled and that the accused has completely regained his free individual will. ${ }^{87}$

On the other hand, Mr. Chief Justice Stone, with the concurrence of Justices Roberts, Reed, and Jackson, voted to affirm the judgments as to both Malinski and Rudish. It was their view of the record that Malinski's first confession had not been submitted to the jury, except to show whether the second confession had been coerced, and that under the rule of Lyons v. Oklahoma the jury's verdict conclusively established that the second confession was voluntary.

While nominally affirming Rudish's conviction, the Supreme Court invited the state court to consider whether the reversal as to Malinski would, as a matter of state law, affect the judgment against Rudish. The New York Court of Appeals accepted the invitation, and directed that "in the interest of justice" Rudish should have a new trial with Malinski's confession excluded.8

In United States v. Mitchell the Court observed that,

in cases coming from the state courts in matters of this sort, we are concerned solely with determining whether a confession is the result of torture, physical or psychologi-

${ }^{27}$ Ibid., at 433 .

${ }^{88}$ People v. Rudish, 294 N.Y. 500, 63 N.E. 2d 77 (I945). 
cal, and not the offspring of reasoned choice. How difficult and often elusive an inquiry this implies, our decisions make manifest. ${ }^{89}$

Although it is not possible to fit the cases into neat categories, since each turns to a considerable extent on its particular facts, some general principles have emerged. The rack, the wheel, the knout, and other more subtle but equally compelling forms of physical mistreatment, are beyond the pale; confessions obtained by such means contravene the Due Process Clause. The same is true of confessions produced by employing the more vicious types of non-violent third-degree practices. But, "the mere questioning of a suspect while in the custody of police officers is not prohibited either as a matter of common law or due process," a confession is made while an accused is in the custody of police officers does not render it inadmissible. ${ }^{9 x}$ Between those limits of the clearly permissible and the clearly forbidden lies an area of disagreement in which the Lisenba, Lyons, and Malinski opinions stand as visible but wobbly guideposts.

The Supreme Court naturally has a great concern that it avoid interfering with state criminal proceedings except where there is clear indication that the state has not respected "those minimal historic safeguards for securing trial by reason which are summarized as 'due process of law." "92 But, as this whole development demonstrates, in recent years "due process of law" has been an expanding concept in its application to state criminal proceedings. It may yet move toward the point where any confession will be deemed to be of very dubious validity merely because obtained while state officials were acting in violation of the basic safeguards which state law has thrown around an arrested suspect. The fear that this would unduly fetter the law enforcement efforts of the states is not frivolous, but there are good reasons to believe that it is a fear without foundation. Federal investigators, who are denied the benefits of confessions obtained from accused persons while held illegally, nevertheless manage to secure convictions; and Great Britain, where the secret interrogation of a suspect is not tolerated, is hardly a land given over to the lawless. The numerous statutory requirements for prompt arraignment, and the prohibitions against illegal detention, are indicative of the extent

${ }^{89} 322$.U.S. 65,68 (I944).

${ }^{90}$ Lyons v. Oklahoma, 322 U.S. 596, 60I (I944), citing Lisenba v. California, $3^{\text {I } 4}$ U.S. 2I9, 239-4x (194I), and Wan v. United States, 266 U.S. I, I4 (x924).

9x United States v. Mitchell, 322 U.S. 65 (I944); McNabb v. United States, 3I8 U.S. 332 (I943).

${ }_{92}$ McNabb v. United States, 3 I8 U.S. 332, 340 (I943). 
to which our ideal of fairness to the individual is at war with the Gestapolike practices of the dragnet and the secret interrogation-practices which have a way of being used most often against the untutored, the unfortunate, the unpopular, and the uninfluential. In the words of the Supreme Court, those statutory requirements reflect "not a sentimental but a sturdy view of law enforcement"; they outlaw "easy but self-defeating ways in which brutality is substituted for brains as an instrument of crime detection." 93

A long step would be taken toward the realization of a truly civilized system of criminal law enforcement if the state courts would, without awaiting compulsion from the Supreme Court, ${ }^{94}$ follow the lead of the Supreme Court in the $M c N a b b$ and Anderson cases and refuse to condone illegal acts on the part of state authorities, however well-intentioned. ${ }^{95}$ There would then be little chance that a state would be subject to the recurrent humiliation of defending before the Supreme Court and the nation the sorry circumstances under which a "confession" had been wrenched from an accused.

\section{TAINTED TESTIMONY}

Another restriction upon the states was evoked by Tom Mooney's application to the Supreme Court for a writ of habeas corpus. Mooney's death sentence in I9I6, for participation in a bomb explosion that killed ten persons in San Francisco's Preparedness Day parade, ${ }^{96}$ had been com-

93 Ibid., at 344. The statutory requirements are there collected. There is eminent authority that the questioning of suspects held illegally tends to encourage inefficiency on the part of law enforcement officials. See Report of Comm. on Lawless Enforcement of the Law (Amer. Bar Ass'n), I Amer. Jour. Police Sci. 575, especially 588 (I930); IV National Commission on Law Observance and Enforcement, Reports 4, 5, 35 et seq., I 52, I59 (I931); Glueck, Crime and Justice 76 (1936).

94 Or from Congress, in the exercise of its power, under section 5 of the Fourteenth Amendment, "to enforce, by appropriate legislation, the provisions" of that Amendment.

95 In the Malinski case, however, the New York Court of Appeals unanimously took the view that, because of long-settled judicial decisions adopting a rule contrary to the McNabb case, it would require an act of the legislature to alter the rule. People v. Malinski, 292 N.Y. $360,37 I, 387,55$ N.E. 2d 353, 357, 365 (I944). The McNabb rule has been rejected by three other state courts of last resort. State v. Browning, 206 Ark. 79I, I78 S.W. 2d 77 (I944); Hall v. State, 189 S.W. 2 d 917 (Ark., I945); State v. Folkes, I74 Ore. 568, I50 P. 2 d 17 (1944); McGhee v. State, I89 S.W. $2 d 826$ (Tenn., I945); see State v. Smith, I58 Kan. 645, I49 P. 2d 600 (I944). It was the subject of somewhat hostile dicta in Finley v. State, I53 Fla. 349, 396, I4 So. 2d 844-45 (I943); Bryant v. State, 197 Ga. 641, 646, 30 S.E. 2d 259, 263 (r944); see also State v. Golden, 353 Mo. $585,599,183$ S.W. 2 d Iog, II 5 -I6 (1944). It was given favorable recognition in principle but was not applied in practice in Fry v. State, 147 P. 2d 803 (Okla. Cr. App., I944).

96 Mooney v. State, I75 Cal. 666, I66 Pac. 999 (1917), I76 Cal. I05, I7I Pac. 690 (Igr8), I 78 Cal. 525, 74 Pac. 325 (Igr8), cert. denied, 248 U.S. 579 (Igr8). 
muted by the governor to life imprisonment upon the intervention of President Wilson. In his I934 application to the Supreme Court of the United States, Mooney alleged, with abundant specifications, that the sole basis of his conviction was perjured testimony knowingly used by the prosecuting authorities, and that the prosecution deliberately suppressed evidence which would have impeached and refuted the testimony against him. The Supreme Court ruled that the Due Process Clause forbade a contrivance by a state-acting through its prosecuting officers-to procure a conviction by the presentation of testimony known to be perjured, and that corrective judicial process should be afforded to remedy such a wrong. The Court, however, denied leave, without prejudice, to file the petition on the ground that it did not appear that corrective process was wholly unavailable in California state courts. ${ }^{97}$ On a subsequent hearing of Mooney's charges, the Supreme Court of California ruled that the allegations had not been established by "substantial, credible evidence."98

In four subsequent cases the Supreme Court of the United States has held that men convicted in state courts were entitled to hearings on their charges that the prosecution had knowingly used perjured testimony. ${ }^{99}$ It is sufficient to say, without elaborating the details, that in each of the four cases the testimony in question was directly material to the conviction.

In none of the cases, nor in the Mooney case, did the Supreme Court undertake to prescribe in advance the kind of hearing which due process required. The extent to which affidavits may be relied on, the necessity of taking oral testimony, the degree of reliance which may be placed upon

97294 U.S. 103 (I935).

${ }_{98}$ Ex parte Mooney, Io Cal. 2d I, 73 P. 2d 554 (1937), cert. denied, 305 U.S. 598 (I938), with Justices Black and Reed dissenting. In January, I939, Mooney was pardoned by Governor Olsen, who declared his belief in Mooney's innocence. New York Times, January 8, 1939.

99 Pyle v. Kansas, 317 U.S. 213 (I942); People ex rel. Whitman v. Wilson, 318 U.S. 688 (I943); Ex parte Hawk, 32I U.S. II4 (I944); Lutz v. Ragen, 324 U.S. 760 (I945). In the Whitman case, the Supreme Court vacated the judgment to give the New York courts an opportunity to decide whether, under state law, habeas corpus could be used as a remedy alternate to the writ of error coram nobis. The Court of Appeals held coram nobis the exclusive remedy, thus terminating Whitman's habeas corpus proceeding. Morhous v. Supreme Court of New York, 293 N.Y. 13I, 56 N.E. 2d 79 (1944). Whitman then instituted a coram nobis proceeding; after a hearing, the court found his allegation's were not supported by any credible evidence. People v. Whitman, 185 Misc. 459, 56 N.Y.S. $2 d 890$ (I945). On the remand of the Pyle case, after long delays on the part of Pyle's counsel, his amended petition was dismissed on the ground that it did not comply with the Kansas Supreme Court's order that it be made more definite and certain on a number of crucial items. Pyle v. Amrine, r 59 Kan. 458, r56 P. 2d 509 (I945), cert. denied, 66 Sup. Ct. 45 (I945). 
written records-all such matters the Court quite plainly is attempting to encourage the states to work out for themselves in the first instance. In Hysler v. Florida ${ }^{\text {100 }}$ the Court stated that "the Due Process Clause did not stereotype the means for ascertaining the truth" of such a claim; and that:

Each state may decide for itself whether, after guilt has been determined by the ordinary processes of trial and affirmed on appeal, a later challenge to its essential justice must come in the first instance, or even in the last instance, before a bench of judges rather than before a jury. ${ }^{\text {.0x }}$

Moreover, in the Lisenba case ${ }^{\mathrm{ro2}}$ the Court appears to have allowed California considerable leeway to reject affidavits without taking testimony, and in Hawk v. Olson ${ }^{\text {ro3 }}$ it accepted the ruling of the Supreme Court of Nebraska that the allegations as to perjured testimony were conclusions of law which under local procedure must be supported by additional specifications.

${ }^{100} 315$ U.S. 4 II (1942). The case involved a belated claim that Hysler's two co-defendants had testified falsely against him (he had been sentenced to death for murder) because they were "coerced, intimidated, beaten, threatened with violence and otherwise abused and mistreated" by the police, and were "promised immunity from the electric chair" by the district attorney. Hysler's application for a writ of error coram nobis, which was supported by affidavits of recantation from one of the co-defendants, was denied by the Florida Supreme Court. The majority of the Supreme Court of the United States thought that the Florida court had considered the credibility of Hysler's allegations, and found them insubstantial-a finding which was held justified in view of the lengthy prior proceedings and many other circumstances suggesting the implausibility of the supporting affidavits. Three justices, in dissent, urged ( $\mathrm{r}$ ) that the Florida court had not passed on the credibility of the allegations but had ruled that the allegations, even if true, would not have precluded Hysler's conviction, and (2) that, if the allegations were true, Hysler's conviction was tainted with a measure of brutality sufficient to establish a violation of his constitutional rights.

It should be noted that the Court has not yet been forced to decide whether the Due Process Clause requires that collateral attack be permitted on a conviction resting on a coerced confession (Florida, under its rules of practice, voluntarily permitted collateral attack in the rather extreme circumstances disclosed in the Chambers case, note 59, supra).

sor Ibid., at 4 r 7 .

${ }^{102}$ While Lisenba's appeal from the murder conviction was still pending on rehearing in the California Supreme Court, he filed in that court an original application for habeas corpus. The application was found on affidavits by his co-defendant Hope-who had received a life sentence after pleading guilty and serving as the principal witness for the state-that Hope's testimony had been induced by coercion and promises and had been known by the prosecution to be perjured. The court denied the application for habeas corpus without requiring an answer from the state and without taking oral testimony. The Supreme Court, in affirming, stated that a refusal to believe Hope's affidavits would be no denial of due process. 3I4 U.S. 219, 226-27 (I94I). It should be noted, however, that the truthfulness of Hope's testimony had been elaborately inquired into at the trial, so that the California court had before it an extensive record with which to compare the allegations in his affidavits. Moreover, the application for habeas corpus had been denied "without prejudice," possibly leaving the way open for a similar application to the trial court.

10366 Sup. Ct. II6, II7 (1945). 


\section{ACCESS TO THE COURTS}

The Supreme Court has twice castigated state prison officials for interfering with the free access of prisoners to the courts. ${ }^{\mathrm{x}}{ }^{04}$ In addition, Cochran v. Kansas ${ }^{55}$ established the effectiveness of the Fourteenth Amendment in assuring corrective process to a defendant if his appeal papers are suppressed by state officials. In I933 Cochran had been convicted in a Kansas state court for uttering a \$I 2.60 forged check and received a life sentence as an habitual criminal. In I94I he applied to the Kansas Supreme Court for habeas corpus, alleging that penitentiary officials had suppressed appeal papers he had prepared, thus making it impossible for him to perfect his appeal within the prescribed two-year period. The writ was denied without inquiry into the truthfulness of his story. The Supreme Court of the United States reversed, holding that Cochran's allegations, if true, established a violation of the Equal Protection Clause, and that the state court should have inquired into their verity. The Kansas Supreme Court then conducted an extensive hearing and resolved the factual issues against Cochran. Its opinion leaves the impression that, with respect to controverted documents on which he particularly relied, Cochran, having forged his way into prison, was attempting to forge his way out. The court specifically found:

that the prison officials did not frustrate the petitioner's efforts to perfect an appeal .... that despite his conversations and correspondence with his attorney who represented him at the trial and with other attorneys, and his freedom to write to the clerk of the district court and the county attorney, he made no effort to take the steps necessary under the law to effect an appeal .... that the attitude of Warden Simpson toward the petitioner was kindly and designed to be helpful, and that he never destroyed any court papers which the petitioner desired sent out, nor authorized any of his subordinate officials to do so. ${ }^{\text {.06 }}$

A petition for certiorari was denied, ${ }^{\mathbf{x} 7}$ leaving Cochran in the penitentiary.

\section{CONCLUSION}

Sufficient time has not yet elapsed to judge whether the Supreme Court's decisions in the cases under discussion have had a permanent impact on the mores of state police, prosecutors, and criminal court officials - the authorities responsible for administering the great mass of state

so4 White v. Ragen, 324 U.S. 760, n. I (I945); Ex parte Hull, 3 2 U.S. 546 (194I).

ros 3 I6 U.S. 255 (I942).

${ }^{106}$ Cochran v. State, I55 Kan. 777, 79I, 792, 130 P. 2d 79I (1942); I56 Kan. 216, 221, I33 P. 2d 9I (I943).

${ }^{207}$ Cochran v. Kansas, 3 I9 U.S. 745 (1943). 
criminal cases that never reach the Supreme Court, or, indeed, any appellate court. Undoubtedly there is a belief in some quarters that judicial reversals of criminal convictions can never operate as an effective deterrent which will prevent state law-enforcement officials from forgetting the solemn duties entrusted to their care. Even if that were true, the Supreme Court's intervention in these cases under the Fourteenth Amendment has at least assured to the particular defendants a trial free from the procedural taints which run counter to our notions of fundamental justice to the individual. But it is certainly not excessive optimism to expect that, gradually but perceptibly, the principles of law enforcement expressed in these Supreme Court decisions may become, as the Constitution contemplates, the supreme law of the land in fact as well as in theory. The nuisance and the expense of affording a fair retrial to even the most obviously guilty defendant is a small price to pay for that result. 